\title{
Proceeding
}

Supplementary Issue: Summer Conferences of Sports Science. $8^{\text {th }}$ International Workshop and Conference of the International Society of Performance Analysis of Sport (ISPAS), 11-1 th of September 2019 (Budapest, Hungary) "Technology meets Practice and Science".

\section{Learning the service drills in novice volleyball athletes}

\author{
DANTE FORTE ${ }^{1} \triangleleft$, TIZIANA D'ISANTO¹, FELICE DI DOMENICO'1, GAETANO ALTAVILLA² \\ 1 University of Salerno, Italy \\ 2University of Split, Croatia
}

\begin{abstract}
Volleyball service is the fundamental element with which the game begins; it can be carried out from below, from a floating top, or from above in a jump. This article discusses the changes in speed and accuracy of service as a result of different training methods. A sample of 33 participants with no experience in volleyball was divided into three groups. Two groups carried out three weeks of training, the first following the ecological approach, in complete freedom, the second group following the mixed method (global-analytical-global) while the third group formed the control group. The participants were evaluated in advance and on two successive occasions. In each test, accuracy and speed of service were recorded. The results highlight the improvement in the accuracy and speed of the practice groups. In addition, the mixed training group presented greater consistency in accuracy, decreasing the variable error of their attempts. The main conclusion of the study is that the mixed training methodology can be a very effective method for learning the service in volleyball with inexperienced populations. Keywords: Motor learning; Performance; Skills; Training; Analytical learning; G.A.G. (Global-Analytic-Global).
\end{abstract}

\section{Cite this article as:}

Forte, D., D'Isanto, T., Di Domenico, F., \& Altavilla, G. (2019). Learning the service drills in novice volleyball athletes. Journal of Human Sport and Exercise, 14(5proc), S2419-S2428. doi:https://doi.org/10.14198/jhse.2019.14.Proc5.57

\footnotetext{
Corresponding author. University of Salerno, Italy.

E-mail: danteforte@outlook.it

Supplementary Issue: Summer Conferences of Sports Science. $8^{\text {th }}$ International Workshop and Conference of the International Society of Performance Analysis of Sport (ISPAS), 11-13 th of September 2019 (Budapest, Hungary).

JOURNAL OF HUMAN SPORT \& EXERCISE ISSN 1988-5202

(c) Faculty of Education. University of Alicante

doi:10.14198/jhse.2019.14.Proc5.57
} 


\section{INTRODUCTION}

Both the learning and the training (Raiola et al 2012, 2013) of the sports technique, have traditionally been based on the repetition of a "model" gesture to get the best out of it. This method of training the technique, is applied mainly for the improvement of individual actions, because then they are repeated "apparently" in the same way in the race. In our study new perspectives emerged with different approaches to optimize performance in technical training. On the basis of these new perspectives, the variability of movement, far from being considered a mere error, is considered necessary for the athlete's motor adaptations, avoiding a loss of complexity of the system.

Thus, deviations from a "model" or "ideal" movement are interpreted as fluctuations in the organization of the movement that are relevant to the processes of motor adaptation.

The influence of these fluctuations on system adaptation provides the basis for the G.A.G. (Global-AnalyticGlobal) Methodology. The main assumption on which this methodology is based is the different learning capacity that can be obtained by subjecting an exercise to the whole of the team compared to the responses that an individual analytical exercise can give.

For this reason, therefore, the methodology (D'Elia et al, 2019, Raiola, 2019, 2017, 2014ab, 2013, Valentini et al 2018 ) is prepared as the unpacking of the complexities in individual analytical exercises, thus developing first exercises of an analytical nature and only once you become aware of the gesture is implemented a collective global exercise.

\section{Motor learning}

Motor learning in Jean Pierre Famose is defined as the engine of the construction of an athlete, it is seen as a set of internal operations that involve a more or less constant variation in the performance of the subject.

The acquisition of teaching is a mental process that interacts with the environment and therefore the role of the educator will be to prepare situations, suitable to develop or improve new behaviours.

\section{Analytical (or fractional) learning}

Fractional learning seeks to break down the complexities of learning a complex sport such as volleyball.

The analogy is: when the student wants to learn to read as a first step he learns to syllable, in the same way in volleyball as in school, he wants to implement an activity of decomposition of difficulties.

This method is, however, very complex in the field of sport, in fact, we must implement a coherent fractioning in which each step is preparatory to the next step.

The aim of this study is to compare the changes in speed and precision in the shot from below in volleyball in athletes without experience (Altavilla G. et al 2015, D'Isanto et al 2018, Valentini et al 2018) using different methodologies.

In this way we expect the G.A.G. group to increase the performance of inexperienced participants in a closed skill such as volleyball service (Alminni C et al,2019, D'Isanto et al 2017, Parisi F. 2014, Raiola et al 2016, Wulf G. et al 2002). 


\section{METHOD}

A sample of 33 participants with no experience (Duncan MJ et al 2006) in volleyball was divided into three groups (Gabbett T et al 2007). Two groups carried out three weeks of training, the first following the ecological approach (AE), in complete freedom, the second group following the mixed method GAG (global-analyticalglobal) while the third group formed the control group (GC) not making any training but attending the demonstration of the technical gesture. The participants were evaluated in advance and on two successive occasions. In each test, the accuracy and speed of service (Ferrara et al 2018,2019) were recorded.

The distribution in the various groups was random and detailed in table 1.

Table 1. Sample descriptions by group.

\begin{tabular}{llll}
\hline & GAG & AE & GC \\
\hline N & 11 & 11 & 11 \\
AGE & $11 \pm 0.82$ & $11 \pm 0.92$ & $11 \pm 0.90$ \\
HEIGHT $(\mathrm{cm})$ & $159 \pm 5$ & $161 \pm 5$ & $163 \pm 4$ \\
WEIGHT (KG) & $56.55 \pm 8.23$ & $56.18 \pm 3.87$ & $54.18 \pm 6.05$ \\
\hline & GAG= Global Analytical-Global; AE= The Ecological Approach; GC= Control Group.
\end{tabular}

Before starting the study, participants were informed of the procedure and timing that will be used in this study, giving their explicit consent to participation (Altavilla G. et al., 2017, Forte \& Altavilla, 2018; 2019).

\section{Tools}

The measurement of the velocity of the ball in the action of beating from below has been calculated using the mathematical formula of speed (Speed $=$ space/time) recording with an iPhone 7 the action to obtain the flight time while the distance from the target has been detected with the help of a metric roll (Raiola et al 2013,2014,2015). The device was positioned behind the athlete, so that the camera caught the target from the moment of touching the ball to its destination. The recordings were digitized using Kinovea software 0.8.15.

The ball used was the Mikasa MVA 200, 260-280 gr. approved by the International Volleyball Federation.

\section{Variables}

The independent variable was the training method, the effect of which was studied through tests (initial, final and retention) on the two experimental groups and the control group. The dependent variables were speed, measured in $\mathrm{m} / \mathrm{s}$, and accuracy.

\section{Procedure}

The treatment consisted of an initial test, 12 training sessions (divided into three weeks), a final test the day after the learning phase and a retention test three days after the treatment (fig. 1).

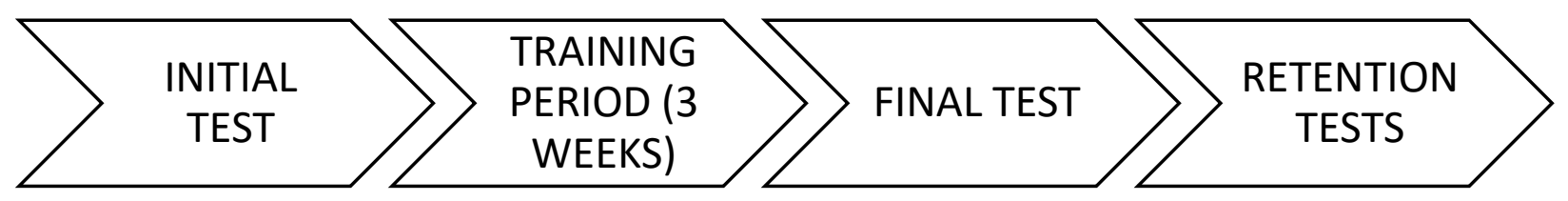

Figure 1. Treatment program. 
A meeting was held before the initial test to demonstrate the correct technique of the service.

Before the initial test, the athlete began a warm-up routine, led by the research group.

The test consisted of four sets of eight services (Fialho, J. V.et al 2006) in the direction of a target placed in the other field (zone 1 of the field, next to the side-line, see fig. 2). Only the best result of each test was taken into account.

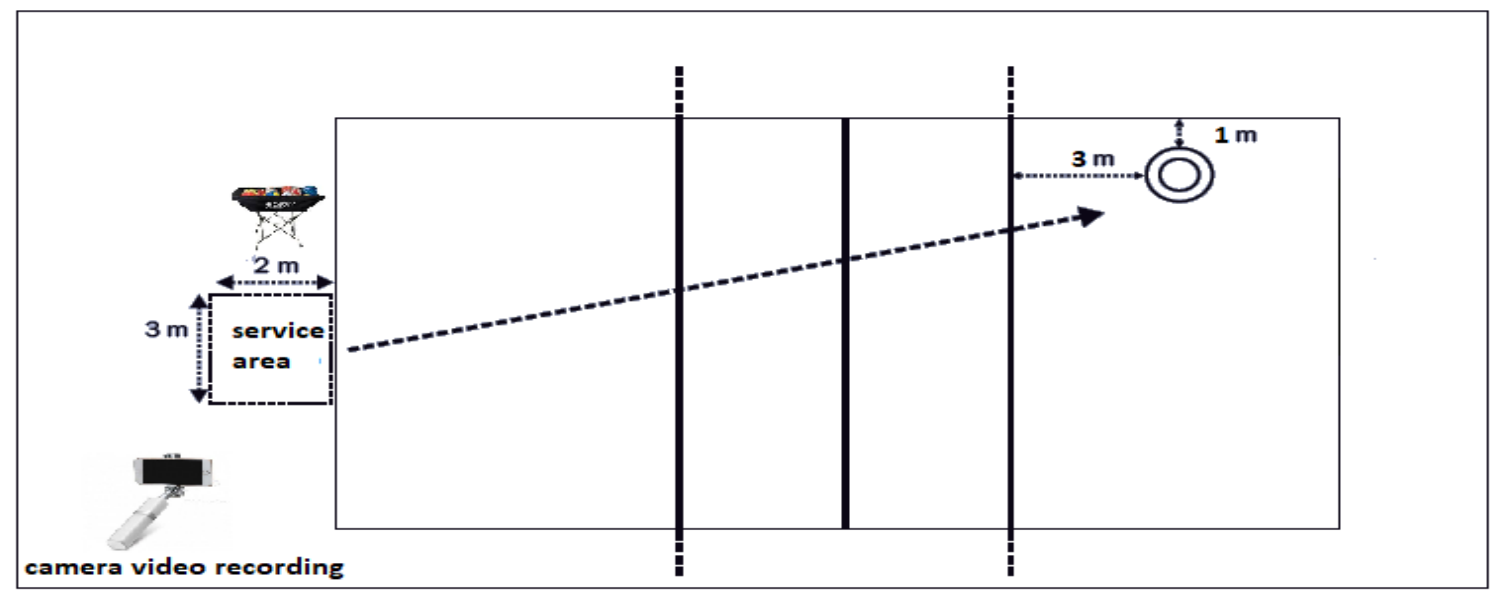

Figure 2. Research environment structure.

The trajectory of the ball had to be higher than the height of the net and between one serving and the next there were five-second breaks and 60 -second breaks between one series and the next.

During the training session, the GAG group followed 3-stage training sessions:

\section{- Global 1:}

After the warm-up, it starts with a first phase of exercise which must be a simplified form of the result you want to achieve in the final form, so players can discover and experience the "real" game. The coach observes and analyses without interfering or correcting (corrections are not desired at this stage).

\section{- Analytical:}

In the next section, of an analytical type, the focus is on the exercise and development of specific technical aspects that you want to train in this training session and that are recurrent in the 3 phases of exercises proposed. The role of the coach in this phase is to train, then teach and demonstrate the correct way to perform this specific aspect and correct its players later on according to the difficulties.

\section{- Global 2:}

The exercise takes up the theme developed first in the global form and then in the analytical form. This section allows you to apply what has been exercised and often takes the form of a game similar to Global-1, in this phase the role of the coach is to correct its players, stimulate, find alternatives for the correct application of the technical gesture or the trained aspect.

The $A E$ group provided its services under the premise of repeating the technical gesture that had been presented at the beginning of the investigation, without receiving instructions and corrective measures. 
The GC group did not conduct any training.

\section{RESULTS}

Table 2. Comparative table.

\begin{tabular}{|c|c|c|c|}
\hline & Initial Test & Final Test & Retention Test \\
\hline \multirow{2}{*}{\multicolumn{4}{|c|}{ Control group }} \\
\hline & & & \\
\hline Average speed & $8.40 \pm 1.75$ & $8.50 \pm 1.75$ & $8.60 \pm 1.75$ \\
\hline Distance to target & $3.02 \pm 2.38$ & $3.10 \pm 2.40$ & $3.05 \pm 2.38$ \\
\hline \multicolumn{4}{|l|}{ Ecological approach group } \\
\hline Ecological approach group & $8.11 \pm 1.75$ & $9.11 \pm 1.70$ & $9.15 \pm 1.61$ \\
\hline Distance to target & $2.70 \pm 1.86$ & $2.65 \pm 1.70$ & $2.55 \pm 1.86$ \\
\hline Average speed & $8.32 \pm 1.30$ & $9.32 \pm 1.32$ & $9.20 \pm 1.30$ \\
\hline Distance to target & $2.60 \pm 1.75$ & $1.60 \pm 1.30$ & $1.80 \pm 1.42$ \\
\hline
\end{tabular}

\section{Average distance to target difference graph}

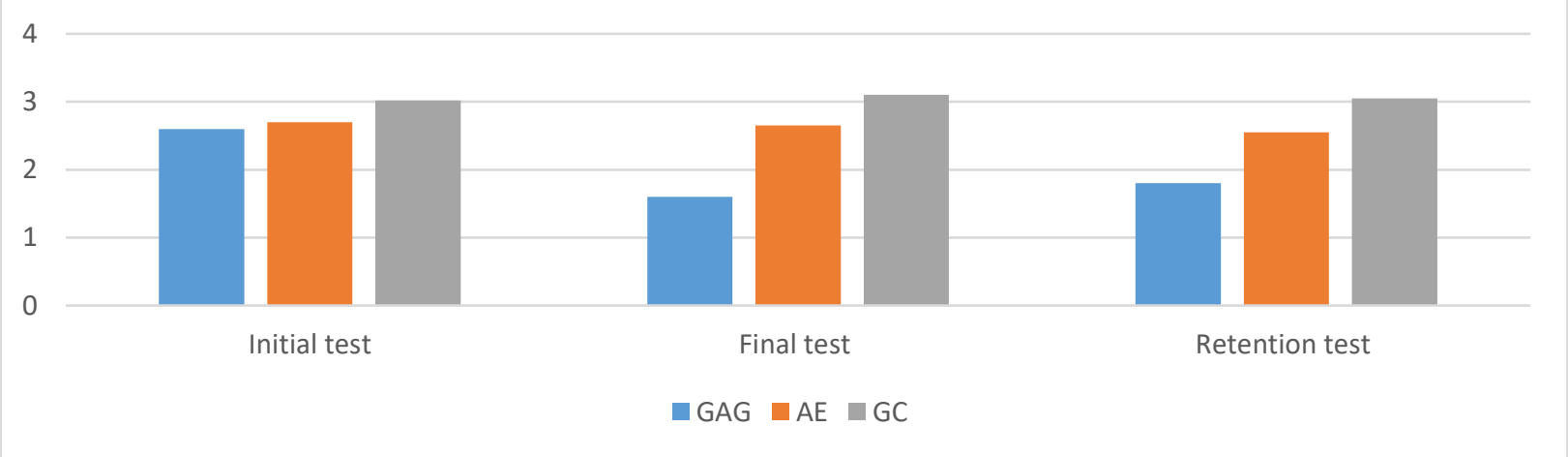

Figure 3. Target distance difference graph. 


\section{Average speed difference graph}

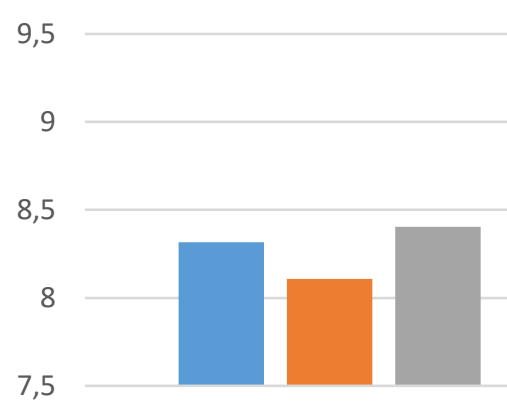

Initial test

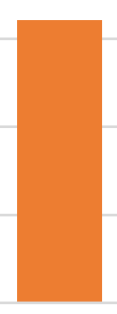

Final test

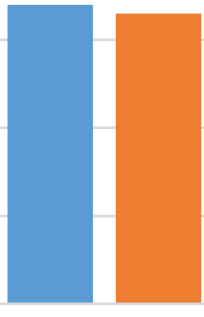

Retention test

$\square \mathrm{GAG} \square \mathrm{AE} \square \mathrm{GC}$

Figure 4. Average speed difference graph.

Table 3. T-Test (initial GC and final retention for speed).

\begin{tabular}{|c|c|c|c|c|c|c|c|c|}
\hline & \multicolumn{5}{|c|}{ Coupled differences } & \multirow{3}{*}{$t$} & \multirow{3}{*}{$g l$} & \multirow{3}{*}{$\begin{array}{l}\text { Sign. (a } \\
\text { due code) }\end{array}$} \\
\hline & \multirow{2}{*}{ Average } & \multirow{2}{*}{$\begin{array}{l}\text { Deviation } \\
\text { std. }\end{array}$} & \multirow{2}{*}{$\begin{array}{l}\text { Standard } \\
\text { error } \\
\text { average }\end{array}$} & \multicolumn{2}{|c|}{$\begin{array}{l}\text { Difference confidence } \\
\text { interval di } 95 \%\end{array}$} & & & \\
\hline & & & & Inferior & Higher & & & \\
\hline $\begin{array}{l}\text { VAR00001 } \\
\text { VAR00002 }\end{array}$ & -.20724 & 1.43224 & .43184 & -1.16943 & .75496 & -.480 & 10 & .642 \\
\hline
\end{tabular}

Table 4. T-Test (initial and final retention GC for the distance to the target).

\begin{tabular}{|c|c|c|c|c|c|c|c|c|}
\hline & \multicolumn{5}{|c|}{ Coupled differences } & \multirow{3}{*}{$t$} & \multirow{3}{*}{ gl } & \multirow{3}{*}{$\begin{array}{l}\text { Sign. (a } \\
\text { due code) }\end{array}$} \\
\hline & \multirow[t]{2}{*}{ Average } & \multirow{2}{*}{$\begin{array}{l}\text { Deviation } \\
\text { std. }\end{array}$} & \multirow{2}{*}{$\begin{array}{l}\text { Standard } \\
\text { error } \\
\text { average }\end{array}$} & \multicolumn{2}{|c|}{$\begin{array}{l}\text { Difference confidence } \\
\text { interval di } 95 \%\end{array}$} & & & \\
\hline & & & & Inferior & Higher & & & \\
\hline $\begin{array}{l}\text { VAR00001 } \\
\text { VAR00002 }\end{array}$ & -.02727 & 2.73901 & .82584 & -1.86737 & 1.81282 & -.033 & 10 & .974 \\
\hline
\end{tabular}

Table 5. T-Test (initial AE and final retention for speed).

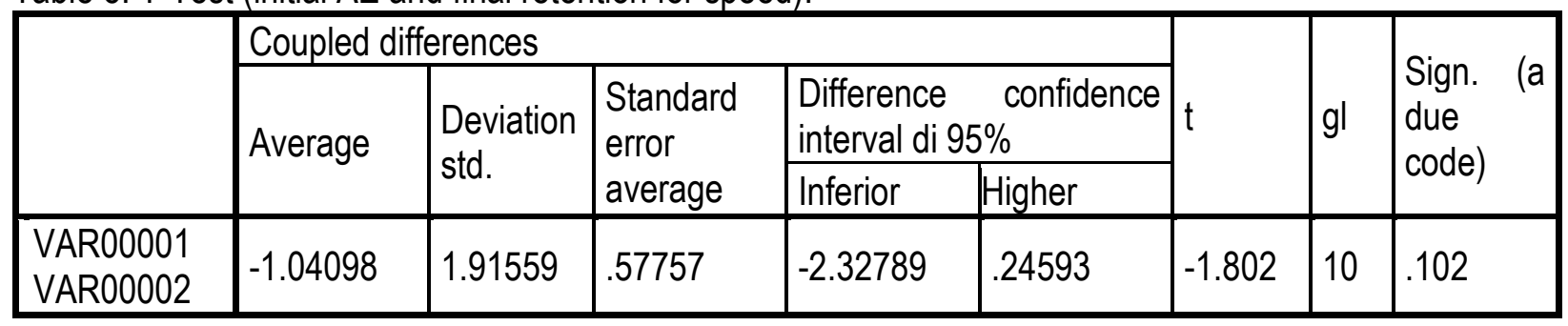


Table 6. T-Test (initial AE and final retention for distance to target).

\begin{tabular}{|c|c|c|c|c|c|c|c|c|}
\hline & \multicolumn{5}{|c|}{ Coupled differences } & \multirow{3}{*}{$\mathrm{t}$} & \multirow{3}{*}{ gl } & \multirow{3}{*}{$\begin{array}{l}\text { Sign. (a } \\
\text { due code) }\end{array}$} \\
\hline & \multirow{2}{*}{ Average } & \multirow{2}{*}{$\begin{array}{l}\text { Deviation } \\
\text { std. }\end{array}$} & \multirow{2}{*}{$\begin{array}{l}\text { Standard } \\
\text { error } \\
\text { average }\end{array}$} & \multicolumn{2}{|c|}{$\begin{array}{l}\text { Difference confidence } \\
\text { interval di } 95 \%\end{array}$} & & & \\
\hline & & & & Inferior & Higher & & & \\
\hline $\begin{array}{l}\text { VAR00003 } \\
\text { VAR00004 }\end{array}$ & .14545 & 2.15795 & .65064 & -1.30427 & 1.59518 & .224 & 10 & .828 \\
\hline
\end{tabular}

Table 7. T-Test (Initial and final retention GAG for speed).

\begin{tabular}{|l|l|l|l|l|l|l|l|l|}
\hline & \multicolumn{4}{|l|}{ Coupled differences } & & & Sign. (a due \\
\cline { 2 - 6 } & Average & $\begin{array}{l}\text { Deviation } \\
\text { std. }\end{array}$ & $\begin{array}{l}\text { Standard } \\
\text { error } \\
\text { average }\end{array}$ & $\begin{array}{l}\text { Difference confidence } \\
\text { interval di 95\% }\end{array}$ & Inferior & Higher & & $\begin{array}{l}\text { Sign. } \\
\text { code) }\end{array}$ \\
\hline $\begin{array}{l}\text { VAR00005 } \\
\text { VAR00006 }\end{array}$ & -.96203 & 1.38535 & .41770 & -1.89272 & -.03134 & -2.303 & 10 & .044 \\
\hline
\end{tabular}

Table 8. T-Test (initial and final retention GAG for distance to target).

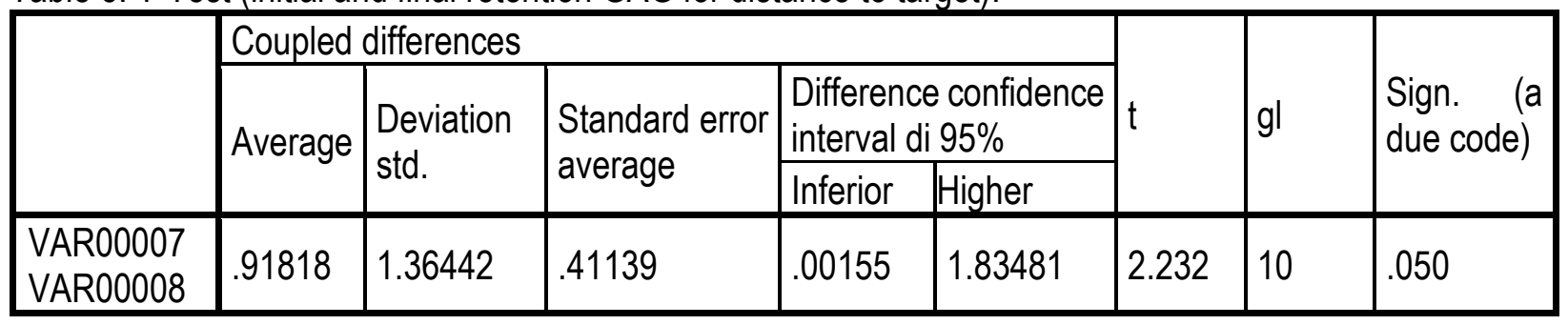

\section{DISCUSSION}

We will comment first of all that the analysis has shown the absence of significant differences between the groups in the initial tests for the variables of distance to target and speed.

Table 2 shows the descriptive statistics for the experimental groups in the three tests.

The target distance variable showed a greater improvement in the GAG group than the other two, which remained almost unchanged.

In relation to the evolution of the mean velocity of hitting the ball, significant differences were obtained in the GAG and AE group between the initial and final tests and retention tests compared to the control group.

Both the GAG group and the AE group statistically improved their speed after treatment, differently in the distance from the target they mainly improved their results the athletes of the GAG group, being improved the accuracy following treatment compared to the other groups.

The statistical analysis, through the t-test, in Tables 7 and 8, confirms the significant improvement in speed and distance to target for the GAG group. 
$>\quad$ In the initial GC T-Test and final retention for speed (0.642) there is no significant difference between the initial test and final retention for speed (tab 3 ).

$>\quad$ Initial and final retention GC T-Test for target distance $(0.974)$ there is no significant difference between initial and final retention test for target distance (tab 4).

$>\quad$ Initial AE and final retention T-Test for speed (0.102) there is no significant difference between the initial test and final retention test for speed (tab 5).

$>\quad$ Initial and final retention AE T-Test for distance to bersaglion (0.828) there is no significant difference between initial and final retention test for distance to target (tab 6).

$>\quad$ T-Test GAG initial and final retention for speed (0.044) there is a significant difference between the initial test and final retention for speed (tab 7$)$.

$>\quad$ GAG initial and final retention T-Test for target distance $(0.050)$ there is a significant difference between the initial and final retention test for target distance (tab 8).

\section{CONCLUSION}

The secret lies in reaping the benefits of each of the two methods (global-analytical), applying them in ideal ways and times. The analytical method is excellent because it allows children to focus on one technique at a time, concentrating and developing it simply but effectively. Ensuring many repetitions, in a context that is at the same time easy to control.

However, you can't just live on the analytical side, completely missing the side related to the game. And it is here that the boys thanks to the global are immersed in the realities of the game. So, finding a context that will facilitate them, managing to apply and find a real use for their techniques. In addition, he also considers the motivational aspect, with the game that leverages the general enthusiasm.

From the results we can suggest that the GAG, applied in learning the service in volleyball, can be useful in the early stages of the process of acquiring this skill.

The control group confirmed that in the absence of practice, suggestions and corrections the margins for improvement are minimal.

The main conclusion of our study is the usefulness of the GAG method in improving performance in precision, while the speed of service is more related to practice.

Based on the above, we can recommend applying the use of the GAG methodology to improve the speed and especially the accuracy of the volleyball service during the process of its learning.

\section{REFERENCES}

Alminni, C., Altavilla, G., Cassese, F.P., Ceciliani, A., D'isanto, T. (2019a) Physical and motor tests to estimate the improvement of the float serve, Journal of Human Sport and Exercise, 14 (Proc2), . S245-S250. https://doi.org/10.14198/jhse.2019.14.proc2.13

Alminni C., Altavilla G., Scurati R., D'Elia F. (2019b) Effects induced through the use of physical and motor tests in volleyball, Journal of Human Sport and Exercise, 14(3proc). https://doi.org/10.14198/ihse.2019.14.proc4.20

Altavilla, G., Furino, F., Di Palmo, M., Raiola, G. (2015) The child hypokinetic and the overtrained, Sport Science, 8, 72-74. 
Altavilla, G., Furino, F., Marika, D.P., Raiola, G. (2015) Physical skills, sport learning and socio-affective education, Sport Science, 8, 44-46.

Altavilla, G., Di Tore, P.A., Riela, L., D'Isanto, T. (2017) Anthropometric, physiological and performance aspects that differentiate male athletes from females and practical consequences, Journal of Physical Education and Sport, 17, art. no. 226, 2183-2187.

D'Elia, F., D'Isanto, T., \& Altavilla, G. (2019). Training and performance in the transition period. Journal of Human Sport and Exercise, 14(2proc), S258-S262. https://doi.org/10.14198/jhse.2019.14.Proc2.15

D'lsanto, T., Altavilla, G., Raiola, G. (2017) Teaching method in volleyball service: Intensive and extensive tools in cognitive and ecological approach, Journal of Physical Education and Sport, 17, 2222-2227.

D'isanto, T., Di Tore, P.A., Altavilla, G. (2018) Correlation of the anthropometric characteristics and the ability to jump in volleyball, Journal of Human Sport and Exercise, 13, S393-S400. https://doi.org/10.14198/ihse.2018.13.proc2.23

Duncan MJ, Woodfield L, Al-Nakeeb Y.Anthropometric and physiological characteristics of junior elite volleyball players. Br J Sports Med 2006;40(7):649-651. https://doi.org/10.1136/bjsm.2005.021998

Ferrara, F., Di Tore, P.A., Gaetano, R. (2018) Preliminary work on the testing of power glove applied to volleyball, Journal of Physical Education and Sport, 18, art. no. 294, 1986-1990.

Ferrara, F., Izzo, R., Ceciliani, A., Di Tore, A.P. (2019)Pilot study on the testing of Power Glove applied to volleyball, Journal of Human Sport and Exercise, 14 (Proc2), S233-S238. https://doi.org/10.14198/jhse.2019.14.proc2.11

Fialho, J. V., Benda, R. N., \& Ugrinowitsch, H. (2006). The contextual interference effect in a serve skill acquisition with experienced volleyball players. Journal of Human Movement Studies, 50, 65-78.

Forte, D., Altavilla, G. (2018) Preliminary correlation between anthropometric and performance data in volleyball about the transition period, Journal of Physical Education and Sport, 18, art. no. 296, 19941998.

Forte, D., Ceciliani, A., Izzo, R., Altavilla, G. (2019) Transition period: Pilot study on performance reduction of ability to jump in volleyball, Journal of Human Sport and Exercise, 14 (Proc2), S221S227. https://doi.org/10.14198/ihse.2019.14.proc2.09

Gabbett T, Georgieff B. Physiological and anthropometric characteristics of junior national, state, and novice volleyball players. J Strength Cond Res 2007;21(3):902-908. https://doi.org/10.1519/r20616.1

Parisi, F., Raiola, G. (2014a) The serve in under 12-13 Italian volleyball team, Journal of Human Sport and Exercise, 9, S588-S591. https://doi.org/10.14198/jhse.2014.9.proc1.51

Parisi, F., Raiola, G. (2014b) Video analysis in youth volleyball team, Journal of Human Sport and Exercise, 9, S584-S587. https://doi.org/10.14198/jhse.2014.9.proc1.50

Raiola, G., (2019) Complex study for an epistemology of Exercise and sport sciences: a) key concepts of both ERC subpanels and CUN keywords; b) Physical training and sport methodology sciences academic disciplines in pedagogy recruitment sector and biomedical one: a correlationships study Journal of Physical Education and Sport vol.19(Supplement issue 5), pp. 1748 - 1754.

Raiola, G. (2017) Motor learning and teaching method, Journal of Physical Education and Sport, 17, art. no. 236, 2239-2243.

Raiola, G., Di Tore, P.A. (2017) Motor learning in sports science: Different theoretical frameworks for different teaching methods, Sport Science, 10, 50-56.

Raiola, G. (2015). Sport skills and mental health. Journal of Human Sport and Exercise, 10(1proc), S369S376. https://doi.org/10.14198/ihse.2015.10.Proc1.27 
Raiola, G., Altavilla, G., De Luca, C., Di Tore, P.A. (2016)Analysis on some aspects of the service in volleyball, Sport Science, 9 (1), 74-77.

Raiola, G. (2014a) Teaching method in young female team of volleyball, Journal of Physical Education and Sport, 14 (1), pp. 74-78.

Raiola, G. (2014b) Motor control and learning skills according to cognitive and ecological dynamic approach in a vision on behaviorism, cognitive, Gestalt and phenomenology theories, Mediterranean Journal of Social Sciences, 5 (15), pp. 504-506. https://doi.org/10.5901/mjss.2014.v5n15p504

Raiola, G., Scassillo, I., Parisi, F., Di Tore, P.A. (2013) Motor imagery as a tool to enhance the didactics in physical education and artistic gymnastic, Journal of Human Sport and Exercise, 8 (2 PROC), 9397. https://doi.org/10.4100/jhse.2012.8.proc2.11

Raiola, G., Parisi, F., Giugno, Y., Di Tore, P.A. (2013) Video analysis applied to volleyball didactics to improve sport skills, Journal of Human Sport and Exercise, 8 (2 SUPPL), 307-313. https://doi.org/10.4100/ihse.2012.8.proc2.33

Raiola, G. (2014) Teaching method in young female team of volleyball, Journal of Physical Education and Sport, 14 (1), 74-78.

Raiola, G. (2013) Body knowledge and motor skills, Knowledge Cultures, 1 (6), pp. 64-72.

Raiola, G., Di Tore, P.A. (2012) Bodily communication skills and its incidence on female volleyball championship to enhance didactics, Journal of Human Sport and Exercise, 7 (2), 365-375. https://doi.org/10.4100/jhse.2012.72.03

Valentini, M., Bernardini, C., Beretta, A., Raiola, G. (2018)Movement and language development as an early childhood twin strategy: A systematic review, Sport Mont, 16 (3), 107-112. https://doi.org/10.26773/smi.181019

Valentini, M., Riccardi, F., Raiola, G., Federici, A. (2018) Educational research: Motor area and relational area during children's personality development, Journal of Physical Education and Sport, 18, art. no. $327,2157-2174$.

Wulf, G., \& Shea, C. B. (2002). Principles derived from the study of simple skills do not generalize to complex skill learning. Psychonomic Bulletin and Review, 9(2), 185-211. https://doi.org/10.3758/bf03196276 